and to noo other plase $w^{t}$ in thies parties of hollande zealande brabant and flanders vppon payne too forfaite for euery clothe other wyse browght or to be conveyde contrarie to this acte $x \times 8$. $8 \hat{\mathbf{t}}$. And for all other comodyteis after the rate / And is further in acted that euerye brother fealishepp hauinge any clothes carseis or otheir whatt 800 meuer the comodytes of the Realme of Ynglande here Remayninge shall cause the same to be fardelled trussed and packed vpp . and the same soo ferdellid packed or trussed . to be shipped. laden . and to be conveyde to barowe by crestmas

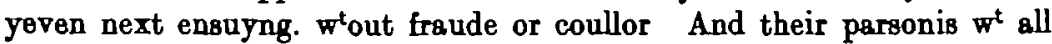
to departe hence to the said towne at the said daye att the ${ }^{1}$ ffurdeste / leade here beinge all Redye $w^{t}$ in this towne of andwerpe is accepted / and that no brother of this fealisheppe after the said daye shal by . sell shew nor delyuer. nor by any means vae feate of marchaundise etheir by him sellfe or any other for him $w^{t}$ in this towne of andwerpe dewringe the contynuance of the said colde marte $w^{\text {tin }}$ the said towne of barrowe vpon payne of one hundred markes sĩ to be forfayted and paid as often es any brother of this fealishepp shalbe found fawtie or directlie or vnderectly doinge in any maner of wyse contrarye to the trewe mesnyng of this ordynance ayther by fraude color or other wyse and is ordeyned that lFes of aduyse shalbe wretten to London and to all other placis whesre anje of the bretherin of this fealishipp dwell and arre presydente to the intent euerye of them maye haue sufficient warnynge and knowledge of the prymisses $\%$

\title{
The Archduke Ferdinand Maximilian and the Crown of Greece, 1863
}

The story of the ill-fated Archduke Ferdinand Maximilian of Austria, who in 1864 became emperor of Mexico, is still in many respects obscure, and it is not probable that a full account of his relations with the Emperor Napoleon III will ever be published. It is, however, of interest and of some historicel importance to discover that only a year before his departure for Mexico he refused a crown in Europe, and that the offer came from the British cabinet. In 1862 the Greeks revolted against their German king, Otho of Bavaria, and he was compelled to leave the country. The Greek assembly declared the throne vacant, and in accordance with the nation's desire invited Prince Alfred of England to become their monarch. But the Palmerston government thought it desirable that the prince should be advised to refuse the honour; the British cabinet at the same time taking upon themselves the responsibility of finding a king for the Greeks. The vacant throne was offered in turn to Ferdinand of Portugal and Duke Ernest of Saxe-Coburg-Gotha. It was on the refusal of the latter that Palmerston and Russell, who was foreign secretary, turned to the Archduke Maximilian.

$$
1 \text { fo. } 152 .
$$


Their first step was to try to ascertain the views of Napoleon III, and the first document dealing with the negotiation is the copy of a telegram ${ }^{1}$ from Russell to Earl Cowley, the British ambassador in Paris, dated 11 February 1863. This reads, "Would the Emperor of the French support the Archduke Maximilian for the throne of Greece?' On the following day Russell sent a second telegram ${ }^{2}$ to Cowley: 'Act upon my instruction of yesterday. The Archduke Maximilian has no children, but might adopt an heir who would embrace the Greek church.' At 7 p.m. on the 14th Cowley was able to reply: ${ }^{3}$ 'The Emperor is quite favorable to the Arch Duke Maximilian.'

Meanwhile earlier in this day (14 February) Russell had communicated by telegram with Lord Bloomfield, the British ambassador in Vienna. The message ${ }^{4}$ read :

Endeavour to ascertain whether the Arch Duke Maximilian, the brother of the Emperor, would accept the crown of Greece. Speak to Rechberg ${ }^{3}$ and if necessary to the Emperor on the subject. The Arch Duke would have all the influence of England in his favour and Her Majesty's Government would consider the Ionian Islands " agfe in his hands.

On the 15th, having now received Cowley's reply, Russell was able to send a further telegram to Vienna informing Bloomfield that 'The emperor of the French is quite favorable to the Arch Duke Maximilian'.

Having now launched their project the British cabinet were not left long in ignorance of its fate. During the evening of 15 February, Bloomfield forwarded to Russell the following telegraphic dispatch : ${ }^{7}$

The Emperor, deeply penetrated at this proof of friendship and confidence on the part of the Queen and Her Majesty's Government, regrets that it is not in his power to accept the proposal that the Arch Duke Ferdinand Maximilian should become a candidate for the throne of Greece. I communicated the substance of your lordship's telegram last night to Count Rechberg. His Excellency has just given me the above answer, and on my asking the reason why the Emperor declined the offer, he answered that the relations of His Imperial Majesty with the House of Bavaria rendered it impossible, and that a communication had been lately received from Munich, showing the fixed determination of the Bavarian dynasty not to resign their claims to the Greek throne. I then enquired if the Emperor would be disposed to grant me an audience, that perhaps His Imperial Majesty would reconsider his decision. His Excel-

- Foreign Office List, 27: $147 \overline{7}$.

Ibid. 27 : 1486 .

3 lbid. $27: 1477$.

- Count Rechberg wan the Austrinn minister for foreign ufiairs.

- The British govermment had already decided to terminate their occupation of the islands, es tho islanders were desirous of becoming nembers of the kingdom of Greece.

I Ibid. 7 : $6 \overline{1} 1$. 
lency replied that the Emperor would see me with plessure if I desired it, but His Imperial Majesty had spoken so positively that he could not encourage the supposition that there was at present any likelihood of his changing his mind. He added that the Emperor had ordered him to make known by telegraph to the Arch Duke Ferdinand Maximilian, which was already done, the answer he was to give me, and that he had also telegraphed to Count Apponyi. ${ }^{1}$

However, Palmerston and Russell were not disposed to accept this refusal as final. On the 16th Russell again made use of the telegraph in order to forward a further instruction ${ }^{2}$ to Bloomfield. The wording of this was:

Ask Rechberg to procure an audience of the Emperor, or permission to address yourself directly to the Arch Duke Maximilian. Say that Her Majesty's Government have been greatly disappointed by the answer of Austria. King Otho and the Bavarian dynasty are excluded by a vote of the Greek assembly declaring the throne vacant, and the Bavarian dynasty cannot be restored by force, and never will be restored without force. An Austrian king might induce the Assembly to grant liberal terms to King Otho in respect of his private property. Any other prince to be chosen would be less favourable to Bavaria and the Arch Duke's refusal will not help the Bavarian dynasty. A treaty might be proposed to Bavaria after the recognition of a new king by Great Britain and France. These two Powers are quite agreed in wishing the Arch Duke to accept. It will be a happy termination of the difficulty in Greece if the Arch Duke can agree to accept if chosen.

Acting on this instruction Bloomfield secured an audience of the emperor. This took place on 18 February and forms the subject of the British ambassador's dispatch ${ }^{3}$ no. 86 of the same date. This reads :

I was summoned to the Palace at I o'clock this day and most graciously received. The Emperor at once commenced the conversation by desiring me to express to Her Majesty's Government his deep regret (désespoir was the word used) not to be able to meet their wishes that the Arch Duke Ferdinand Maximilian should become a candidate for the throne of Greece. His Imperial Majesty said he had immediately communicated to his brother the view he took of the proposal of Her Majesty's Government, and that the Arch Duke entirely adopted the reasons which had induced His Imperial Majesty to decline it. The Emperor continued that his relations with the House of Bavaria rendered it totally impossible to entertain the project, that King Otho had not abdicated, and had not, according to the last information he had received from Munich, any intention of doing so. 'But ', I observed to His Imperial Majesty, ' the Greek Assembly has declared the throne vacant.' 'This might be,' replied the Emperor, but ' le colé du droit est avec le Roi Othon', and the principles of Austria's policy in this respect were unchanged. "We stand by the rights of

1 Austrian a mbasador at the court of St. Jaines.

- Foreign Office List, 7 : 648.

Ibid. $7: 651$. 
sovereigns and their dynasties', and as to the kingdom of Greece itself, he could assure me he entirely approved the policy pursued by Austria when the monarchy was created. I here observed that it was no longer a question of creation but of continuation, and that it was with this view Her Majesty's Government were anxious to see placed npon the throne of Greece a sovereign connected with this great and powerful Empire who would be able to assigt in the development of its resources and in whose hands the Ionian Islands would be safe.

His Imperial Majesty replied that he had deeply considered the whole bearings of the question, and he had been glad to have time to do so before seeing me, but he must inform me he could not depart from his original impreasion, though he should have been glad to do what was agreesble to Her Majesty's Government, with whom it was his most earnest desire to act in strict concert on all questions, especially those concerned with the East, but to entertain the proposal of which I was the bearer would only be to create new difficulties for Austria. She was unpopular at Athens. Russia and Italy were incessantly at work endeavouring to counteract the influence of Austria in Greece and its dependencies;--would they not be violently opposed to the establishment of an archduke as sovereign? 'Besides,' said His Imperial Majesty, 'you must permit me to observe it is not very flattering, after proposals of this kind have been bandied about Europe, that the archduke.should have been thought of when all else had failed.' Had the proposal been made immediately after the Queen had declined the offer of the throne to Prince Alfred, a determination on the part of Her Majesty which he should always regret, it certainly would have been much more agreesble to him. I here agid that I was not aware that Her Majesty's Government had made any communication except to King Ferdinand of Portugal and to the Duke of Coburg, and that although His Imperial Majesty objected to the present proposal, I begged leare to draw his attention to the political advantage which the possession of the throne of Greece by an archduke would procure to Anstria in all questions connected with the kast, to ary nothing of that which would be derived from the annexation of the Ionisn Islands, and that if an archduke were sitting upon the Greek throne, more favourable terms would be obtainsble in respect to the private property of King Otho, and other Bavarian interests. The Emperor answered that he could only repest his regret to be unable to entertain the proposal which had been submitted to him, that he must decline it for the reasons he had already given; moreover it included a question of Right and Principle, and that he could not depart from the established policy of his Government in such cases, whilst the sentiments of his own honour and dignity prevented him from considering a project in which the immediate interests of the House of Bavaria were so deeply concerned.

Some further details relative to this audience are contained in a private letter ${ }^{1}$ which Lord Bloomfield addressed to Russell on 19 February. He here says :

From the first words of Count Rechberg on the subject, I feared the project

1 Foreign Office List, 256 : 38. 
would not be entertained by the Emperor, and notwithstanding the constitntionsl system established in the Empire and its success, there is nothing changed in the opinions of the Imperial Family on the rights of sovereigns and the principles on which government should be carried on. ... I hardly thought the Emperor would have shown 80 much decision in the matter, but His Majesty is evidently piqued at the proposal having been made here after its failure in other places, and he and all his family are as proud as Lucifer. He was most gracious in his reception of me, but looked very nervous until he had unburthened himself and was able to talk of other matters besides that which had called forth my request for an audience. Of one thing I have come from him convinced-that he pays close attention to foreign affairs, and if he follows as carefully those of all other departments, he must be a man of no small ability and not pass much time in idleness.

The British government made no further attempt to persuade Francis Joseph to change his decision, but some further correspondence passed between Russell and Bloomfield concerning the project. Lord Bloomfield's dispatch ${ }^{1}$ no. 89 of 18 February contains an account of the interview with Count Rechberg at which he had asked for an audience of the emperor.

Count Rechberg again explained that the Emperor's family relations and close connection with the House of Bavaria obliged him to decline the offer. . . Moreover he (Rechberg) had little confidence in the honest co-operation of France in such a scheme. She would probably act as he believed her to have done when the Duke of Coburg was proposed as a candidate for the Greek throne. General Maquan had been sent to Brussels to see His Royal Highness and to express the readiness of France to support him, and at the same time $\mathbf{M}$. Mocquart sent instructions to the French press to write against him; directions were likewise forwarded to M. Bonrrée at Athens with a large sum of money, to create a French party and to agitate for the Duc d'Aumale. He said Austria could not count on France in such a position; and he believed she had declared her teadiness to support the candidature of an archduke only because by so doing, she met the wishes of Her Majesty's Government, and did a civility by Austria, for she must have known beforehand that the proposal would be inacceptable to Vienna.

Lord Bloomfield, however, goes on to say that,

As far as I can judge from Count Rechberg's observations, it would seem that if the Emperor had not decided at once to reject the proposal, His Excellency might have been disposed to consider it, for he feels that notwithstanding the large sacrifice of men and money its success might necessitate, Austria would gain a strong position and one from which she could exercise a great influence in the East; but he dreaded the unpopularity of the question in Austria, and he feared also lest an ambitious man like the Archduke Ferdinand Maximilian on the throne of Greece might become the signal for a change in the whole policy of Austria in the

1 Ibid. 7 : 0.51. 
Eastern question. He thinks too that Austria has troubles enough nearer home, and that it might be wiser to avoid creating new ones at a distance.

Up to this point the diplomatic correspondence relating to the project leaves us in almost complete ignorance as to the personal feelings of Maximilian himself in the matter. Their nature, however, forms the subject of Lord Bloomfield's dispatch ${ }^{1}$ no. 97 of 21 February. This reads :

I have the honour to inform your Lrordship that Count Rechberg, in requesting me to convey to Her Majesty's Government the thanks of the Archduke Ferdinand Maximilian for their proof of confidence in desiring that he might be called to the Greek throne, and the expression of his deep regret to be unable to meet the wishes of Her Majesty's Government, added that His Imperial Highness adopts all the reasons which induced the Emperor to decline the proposal, and had even commented on them more strongly than the Emperor had done. His Excellency said that I could judge of the Archduke's personal feelings on the subject from the observations he had made, that to any one unacquainted with Greece the throne of the Hellenic Kingdom might have many charms, but he had visited the country and studied it, and that not only was his knowledge of it sufficient to deter him from connecting himself with it officially, but that he was astonished King Otho could entertain the thought of returning to Athens and that His Majesty was not thankful to have left the country for ever.

In 1863, then, Maximilian refused the British offer of a throne in Greece. In 1864 he accepted the throne in Mexico erected for him by Napoleon III. Now there have been various theories put forward to account for Napoleon's desire to enthrone Maximilian in Mexico. There are those who say that the emperor of the French had on foot a grand scheme for 'the regeneration of the Latin race', and that his aim in Mexico was to erect a barrier against any further advance by the Anglo-Saxons of the north over the remaining portions of the American continent. Emile Ollivier, ${ }^{2}$ however, is confident that Napoleon's impelling motive was his theory of nationalities ; in short, that the emperor of the French was planning to add Venetia to the new Italian kingdom. This was to be brought about by the coronation of Maximilian in Mexico, for then Francis Joseph, in gratitude for the honour done his brother, would in return consent to the cession of Venice to Italy. In view of Ollivier's theory. Russell's comment on Maximilian's refusal to accept the Greek throne is of some interest. He wrote to Lord Bloomfield : ${ }^{3}$

I am very sorry Maximilian does not accept. The Greeks would have taken him from France and England, altho' unwillingly, and there would have

- Foreign Office List, $7: 651$.

- Ollivier, L'empire liberal, v. 259.

- Foreign Office List, 336 : 32, 18 February 1863. 
been great security for Austria in the Adriatic. To be sure France might have said, 'Now you are so safe, give up Venice', but to that Austria would have said ' No' to the end of the chapter.

It would seem clear that the evidence relating to the offer to Maximilian of the throne of Greece contains a test of the soundness of Ollivier's theory as to Napoleon's object in sending Maximilian to Mexico. For if Ollivier's theory is to hold, it cannot be admitted that Napoleon III in February 1863 was insincere or even lukewarm in his support of the British project for placing Maximilian on the throne of Greece. If the coronation of Maximilian was to bring about the assent of Austria to the cession of Venice, surely the crowning of Maximilian in Athens was at least as likely to bring about such a result, as was the crowning, a year later, of Maximilian in Mexico City. Russell put his finger on one very definite gain to Austria should Maximilian become king of Greece: 'there would have been great security for Austria in the Adriatic ', but there is no record of Russell or of any one else discovering in what respect Austria would gain by his becoming emperor of Mexico. In fact, Francis Joseph and his government were so little aware of its possessing any advantages that they tried to dissuade Maximilian from embarking on the Mexican adventure, refused to support him with either men or money, and compelled him to renounce all his rights of succession to the Hapsburg dominions. But when the Greek project had been mooted, Count Rechberg had himself admitted ${ }^{1}$ to Lord Bloomfield that 'the possession of the Greek throne by an archduke might be advantageous to Austria in carrying out her Eastern policy', and it was Bloomfield's considered opinion that had Francis Joseph not decided to reject the proposal

Count Rechberg might have been disposed to consider it, for he feels that notwithstanding the \%arge sacrifice of men and money its success might necessitate, Austria would gain a strong position and one from which she could exercise great influence in the East.

'In the offer of a throne to the Archduke Maximilian', says Ollivier," 'Napoleon III perceived an unexpected means of freeing a captive province, and hoped that, satisfied with the gift to his family, Francis Joseph would perhaps consent later to release Venetia.' If this were true the British project for placing Maximilian on the throne of Greece should have presented itself to Napoleon as an opportunity by no means to be let slip. In February 1863 Napoleon's army in Mexico had as yet been unable to capture Puebla. The issue of the campaign might fairly be regarded as doubtful; and to erect a Mexican throne for Maximilian 30,000 French soldiers were toiling in the fever-

\footnotetext{
' Ibid. 7 : 651, Bloomfield's dispatch no. 89.

$=$ Ollivier, v. 250 .
}

VOL. XXXVII.-NO. CXLV. 


\section{ARCHDUKE FERDINAND MAXIMILIAN January}

stricken swamps and parched uplands of his future empire. But in Greece there was a vacant throne. To seat Maximilian on it required a minimum of effort. Russell said positively that the Greeks would take him from England and France. In 1862 England had withdrawn from the Mexican expedition just because she suspected Napoleon of wishing to crown Maximilian in that country; England in 1863 was inviting Napoleon's co-operation in crowning Maximilian king of Greece. If then Napoleon's object was to lay that spectre of Venice which Nigra said 'was roaming along the corridors of the Tuileries ', 1 it seems reasonable to suppose that his support to the British plan for presenting Maximilian with a crown would be of the most willing order.

But beyond signifying to Earl Cowley that he "was quite favorable' to the archduke, Napoleon does not appear to have taken any steps to influence Austria in favour of the project. Indeed, what evidence there is points the other way. Rechberg, as we have seen, 'hardly trusted the honest co-operation of France '; he did not believe Napoleon to be sincere. Moreover, in his dispatch ${ }^{3}$ no. 99 of 21 February, Lord Bloomfield wrote :

With reference to that passage in my despatch No. 89 of the I8th inst. in which I mention Count Rechberg's observations on the support of the proposed candidature of the Archduke Maximilian for the Greek Crown which might be expected from France, I have the honour to report that Prince Metternich ${ }^{3}$ reports to his Government that the Emperor hed spoken to him on this subject, saying that he should approve of the selection but was sure the offer would be declined at Vienna.

This praise is faint indeed.

D. Dawson.

1 Ollivier, v. 259.

3 Austrian ambasedor at Paris.

- Foreign Office List, 7 : 651. 